\title{
PENGEMBANGAN LKPD TERINTEGRASI HOTS UNTUK MENINGKATKAN MOTIVASI BELAJAR PESERTA DIDIK
}

\author{
Nuniati'), Erwin Prasetyo1), Adi Jufriansah"1) \\ 1)Pendidikan Fisika, Fakultas Pendidikan MIPA, IKIP Muhammadiyah Maumere, Sikka, NTT, Indonesia
}

Corresponding author :Nuniati

E-mail :nuniati.01.1998@gmail.com

\section{Diterima 05 November 2021, Direvisi 15 November 2021, Disetujui 18 November 2021}

\begin{abstract}
ABSTRAK
Pelaksanaan Kurikulum 2013 berorientasi pada pengembangan abad ke-21 yang dihadapkan bermacam tantangan. Sebagian perihal yang menimbulkan kasus dalam pelaksanaan kurikulum tersebut, ialah kompetensi guru dibawah rerata pemerintah, tidak meratanya fasilitas pembelajaran online, jam pembelajaran dikurangi dengan menggunakan sistem shift. Penelitian ini dilakukan untuk memberikan solusi pada masalah yang ketiga, yaitu dengan mengembangkan LKPD terintegrasi HOTS guna meningkatkan motivasi belajar peserta didik. Tipe riset ialah pengembangan (R\&D) yang mengacu pada model 4-D models yaitu: Define, Design, Development and Dessiminat. Kelayakan media LKPD terintegrasi HOTS dapat diperoleh dari hasil skor rata-rata validasi, uji coba media LKPD meliputi uji kepraktisan serta uji keefektifan. Kenaikan motivasi belajar peserta didik diperoleh dari nilai Standard Gain motivasi belajar peserta didik. Hasil penelitian menunjukkan bahwa sudah dihasilkan LKPD terintegrasi HOTS yang layak dipakai guna meningkatkan motivasi belajar peserta didik dengan nilai Standard Gain sebesar 0,48 dengan kategori sedang.
\end{abstract}

Kata kunci: HOTS; LKPD; motivasi belajar; R\&D

\begin{abstract}
The implementation of the 2013 Curriculum is oriented towards the development of the 21 st century which is faced with various challenges. Some of the things that cause cases in the implementation of the curriculum, are the competence of teachers under the government average, uneven online learning facilities, reduced learning hours by using the shift system. This research was conducted to provide solutions to the third problem, namely by developing a HOTS integrated Student Worksheet to increase learners' learning motivation. The type of research is development (R\&D) which refers to 4-D models, namely: Define, Design, Development and Dessiminat. Media eligibility of HOTS integrated Student Worksheets can be obtained from the results of validation average scores, student Worksheet media trials include practicality tests as well as effectiveness tests. The increase in learners' learning motivation is obtained from the value of Standard Gain of learn motivation learners. The results showed that hots integrated student worksheets that are worth using to increase the learning motivation of learners with a Standard Gain score of 0.48 with a moderate category.
\end{abstract}

Keywords: HOTS; student worksheet; learning motivation; R\&D

\begin{abstract}
PENDAHULUAN
Pelaksanaan Kurikulum 2013 ialah salah satu upaya pemerintah guna meningkatkan mutu lulusan sesuai dengan tujuan pembelajaran, pergantian Kurikulum 2013 diharapkan bisa menciptakan insan Indonesia yang produktif, kreatif, inovatif, serta afektif lewat penguatan perilaku (ketahui kenapa), keahlian (ketahui bagaimana), serta pengetahuan (ketahui apa) yang terintegrasi. Perihal ini dalam rangka menyambut pertumbuhan kehidupan serta ilmu pengetahuan abad 21, yang mengalami pergerakan baik karakteristik ataupun model pendidikan (Sofyan, 2016).
\end{abstract}

Menurut Mustafa (2020), bahwa kriteria kompetensi yang siswa abad 21 diantaranya adalah (1) pemikiran kritis serta pemecahan permasalahan, (2) komunikasi, (3) kerja sama, dan (4) kreativitas serta inovasi. Berlangsung aktifnya interaksi antara pendidik dan peserta didik akan memperoleh pendidikan yang efisien serta dapat dicapainya tujuan pendidikan yang diharapkan dalam rentang waktu yang sudah ditetapkan, ada tidaknya motivasi belajar sangat berpengaruh terhadap keberhasilan belajar peserta didik. Keberhasilan belajar bisa tercapai apabila pada diri peserta didik terdapat keinginan serta dorongan untuk belajar. Oleh sebab itu, untuk mencapai tujuan pembelajaran 
maka diperlukan sebuah motivasi belajar, dimana motivasi merupakan salah satu kunci keberhasilan dalam belajar. (Emda, A. 2018; Wahyuningsih dkk, 2021).

Dalam dunia pendidikan, mata pelajaran fisika merupakan salah satu ilmu yang memiliki peranan penting dan termasuk bagian dari ilmu pengetahuan alam, pengaplikasian konsep mata pelajaran fisika kedalam kehidupan sehari-hari membutuhkan konsep dan penalaran yang kuat (Putri, 2017). Banyak peserta didik menyatakan fisika adalah salah satu mata pelajaran yang sukar, hal ini dikarenakan mereka harus menghadapi banyak hal yang berbeda dalam pembelajarannya. Paling utama yang berkaitan dengan konsep, definisi, rumus- rumus, serta pembuktian. Sehingga mengakibatkan peserta didik mengalami kebosanan disaat belajar fisika, terlebih lagi belum optimalnya penggunaan strategi pembelajaran dalam tiap proses pendidikan serta tata cara pembelajaran yang digunakan kurang bermacam- macam sehingga membuat peserta didik pasif. Berdasarkan pengamatan peneliti di MA yang merupakan salah satu sekolah di kabupaten Sikka yang mengalami dampak dalam proses pembelajaran pada masa pandemik Covid-19 hingga masa New Normal.

Proses pembelajaran yang awal mulanya tatap muka berganti jadi pendidikan jarak jauh (online) dikarenakan dalam kondisi ini pendidik wajib melaksanakan kewajibannya selaku pengajar serta pendidik wajib membenarkan data ataupun ilmu pengetahuan yang didapat untuk diberikan kepada peserta didik, dengan menggunakan aplikasi pembelajaran online seperti: E-Learning, WhatsApp, Google Classroom, Zoom Meeting, Telegram dan email. Namun pada kenyataannya proses pembelajaran jarak jauh (online) ini tidak efektif karena ada beberapa kendala yang dialami oleh pendidik dan peserta didik, yaitu: jaringan internet yang belum merata karena banyak anak yang pulang kampung, peserta didik belum memiliki handphone android, peserta didik dan guru tidak memiliki kuota internet, peserta didik maupun guru belum betul-betul memahami aplikasi pembelajaran online, serta kurangnya komunikasi antara guru dan peserta didik.

Setelah diberlakukannya New Normal di kabupaten Sikka, sekolah-sekolah pun diizinkan untuk melakukan tatap muka dengan tetap mengikuti protokoler kesehatan tetapi jam pembelajaran dikurangi dan menggunakan sistem shift. Untuk mata pelajaran fisika dalam satu minggu satu kali tatap muka dimana setiap kali tatap muka diberikan waktu hanya satu jam, hal ini juga berdampak pada motivasi dan hasil belajar peserta didik karena seperti yang kita ketahui mata pelajaran fisika adalah mata pelajaran yang setiap materinya membutuhkan perhitungan sehingga dengan waktu yang hanya sekian ini menjadi kendala bagi guru untuk menjelaskan materi fisika secara keseluruhan.

Agar tercapainya tujuan pembelajaran diperlukan sebuah bahan ajar yang dalam kegiatannya dapat melatih proses kognitif dan memaksimalkan pemahaman peserta didik seperti LKPD (Faiza, 2020). Adanya keinginan dan dorongan untuk belajar pada diri peserta didik menyebabkan tercapainya keberhasilan dalam belajar, sehingga dapat dilihat bahwa salah satu kunci keberhasilan dalam mencapai tujuan pembelajaran karena adanya motivasi belajar (Emda, A. 2018; Dhema dan Jufriansah, 2020). Oleh karena itu, dengan tersedianya LKPD terintegrasi HOTS, peserta didik dapat melakukan kegiatan yang mengasah kemampuan mereka dalam menalar dan mengevaluasi sebuah permasalahan serta mengkomunikasikan hasil analisisnya. Jika ini dilatih terus-menerus akan menghasilkan peserta didik dengan keterampilan yang diharapkan sesuai dengan tujuan pembelajaran kurikulum 2013 revisi 2018 terintegrasi HOTS.

\section{METODE PENELITIAN}

Metode penelitian menggunakan data deskriptif kualitatif. Target penelitian adalah 23 siswa kelas X MIA pada semester genap 20202021. Kurikulum yang digunakan adalah kurikulum 2013 berorientasi pada pengembangan abad ke-21 saat ini. Jenis penelitian yaitu pengembangan (R\&D) yang mengacu pada model 4-D models, diagram penelitian disajikan pada Gambar 1.
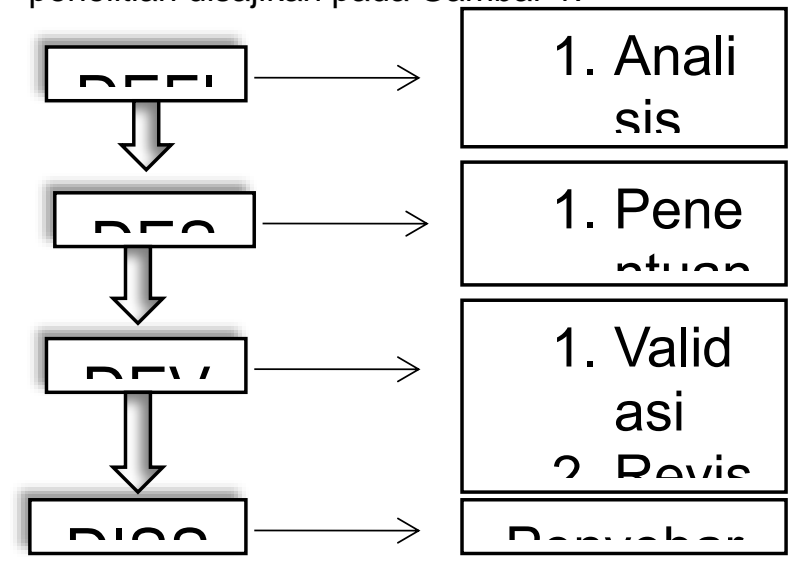

Gambar 1. Diagram Penelitian Tahap Pengembangan Perangkat Pembelajaran Model 4 D

Instrumen dalam penelitian ini adalah dalam bentuk kuesioner validasi oleh ahli, 
kusioner kepraktisan keterlaksanaan pembelajaran, kusioner efektivitas produk yang dikembangkan, dan kuesioner motivasi belajar siswa. Penskoran penilaian LKPD dapat dilihat pada Tabel 1.

Tabel 1. Penskoran Lembar Penilaian LKPD untuk Pernyataan Positif dan Negatif

\begin{tabular}{rll}
\hline Skor & $\begin{array}{l}\text { Kategori } \\
\text { Pernyataan } \\
\text { Positif }\end{array}$ & $\begin{array}{l}\text { Kategori } \\
\text { Pernyataan } \\
\text { Negatif }\end{array}$ \\
\hline 4 & SangatSetuju & $\begin{array}{l}\text { Sangat Tidak } \\
\text { Setuju }\end{array}$ \\
\hline 3 & Setuju & Tidak Setuju \\
\hline 2 & Tidak Setuju & Setuju \\
\hline 1 & $\begin{array}{l}\text { Sangat Tidak } \\
\text { Setuju }\end{array}$ & SangatSetuju \\
\hline
\end{tabular}

Kategori penilaian kevalidan dapat dilihat pada Tabel 2.

Tabel2. Kategori Penilaian validasi

\begin{tabular}{ll}
\hline $\begin{array}{l}\text { Rentang } \\
\text { Kevalidan }\end{array}$ & Kategori \\
\hline $1 \leq \bar{V}<1,8$ & Tidak Valid \\
\hline $1,8 \leq \overline{\bar{V}}<2,6$ & Kurang Valid \\
\hline $2,6 \leq \overline{\bar{V}}<3,4$ & Cukup Valid \\
\hline $3,4 \leq \bar{V}<4,2$ & Valid \\
\hline $4,2 \leq \bar{V}<5$ & Sangat Valid \\
\hline
\end{tabular}

Kategori penilaian keterlaksanaan pembelajaran dapat dilihat pada Tabel 3 .

Tabel3. Kategori Penilaian Keterlaksanaan Pembelajaran

\begin{tabular}{ll}
\hline $\begin{array}{l}\text { Presentase } \\
\text { Keterlaksanaan }\end{array}$ & Kategori \\
\hline$p \geq 90 \%$ & Sangat Praktis \\
\hline $80 \% \leq p<90 \%$ & Praktis \\
\hline $70 \% \leq p<80 \%$ & Cukup Praktis \\
\hline $60 \% \leq p<70 \%$ & Kurang Praktis \\
\hline$p \leq 60 \%$ & $\begin{array}{l}\text { Sangat Kurang } \\
\text { Praktis }\end{array}$ \\
\hline
\end{tabular}

Kategori penilaian keefektifan dapat dilihat pada Tabel 4.

Tabel4. Kategori Penilaian Keefektifan

\begin{tabular}{cl}
\hline $\begin{array}{l}\text { Rentang } \\
\text { Efektifitas }\end{array}$ & Kategori \\
\hline $4,2 \leq \bar{E}<5$ & Sangat Efektif \\
\hline $3,4 \leq \bar{E}<4,2$ & Efektif \\
\hline $2,6 \leq \overline{\bar{E}}<3,4$ & Cukup Efektif \\
\hline $1,8 \leq \overline{\bar{E}}<2,6$ & Kurang Efektif \\
\hline $1 \leq \bar{E}<1,8$ & Tidak Efektif \\
\hline
\end{tabular}

Kategori penilaian tingkat Gain Motivasi Belajar dapat dilihat pada Tabel 5.

Tabel5. Kategori Tingkat Gain Motivasi Belajar Rentang N-
Gain Kategori

$g>0,7 \quad$ Tinggi

\begin{tabular}{cl}
\hline $0,3 \geq \mathrm{g} \geq 0,7$ & Sedang \\
\hline $\mathrm{g}<0,3$ & Rendah \\
\hline
\end{tabular}

\section{HASIL DAN PEMBAHASAN}

Pengembangan LKPD terintegrasi HOTS dilakukan untuk meningkatkan motivasi belajar yang memenuhi beberapa aspek persyaratan, yaitu hasil uji validitas LKPD oleh validator ahli. Hasil dari validasi dan pendapat dari validator ahli setelah itu dilakukan perbaikan, hasil perbaikan jadi fitur pendidikan yang hendak diuji coba pada peserta didik serta jadi pertimbangan pada media LKPD peneliti, uji coba media LKPD meliputi uji kepraktisan dan uji keefektifan. Output fase ini merupakan LKPD terintegrasi HOTS, untuk mengukur kenaikan motivasi belajar peserta didik memakai uji N-Gain motivasi belajar. Gambar 2 adalah diagram hasil validasi LKPD oleh ahli validasi.

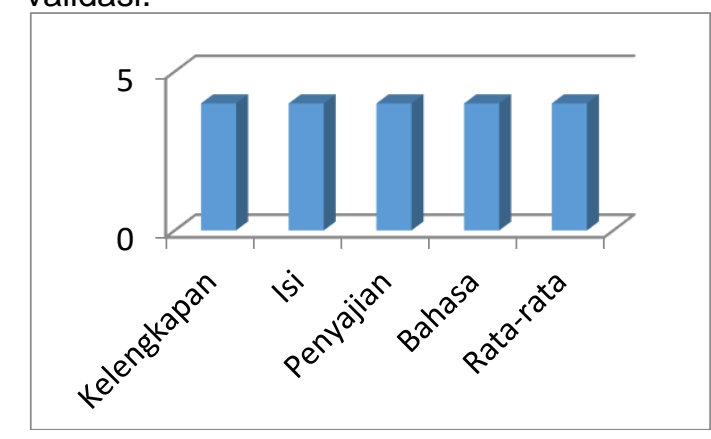

\section{Gambar2. Hasil Validasi LKPD Oleh Ahli Validasi}

Uji kepraktisan dilakukan sesudah proses validasi berakhir serta dipakai guna memperoleh LKPD yang praktis untuk peserta didik. Hasil uji kepraktisan berdasarkan lembar kepraktisan peserta didik memperoleh rata-rata skor 93\% dengan kategori "Sangat Baik" ataupun sangat praktis serta hasil uji kepraktikan guru memeroleh skor $83 \%$ dengan kategori "Baik". Sehingga dihasilkan skor ratarata yang termasuk dalam kategori praktis. Maka dengan kata lain LKPD bisa digunakan dalam proses pembelajaran materi usaha dan energi di kelas $X$. Hasil uji kepraktisan menggunakan pengukuran SPSS juga dapat dilihat pada Tabel 5 dan Tabel 6.

Tabel6. Case Processing Summary

\begin{tabular}{rlrr}
\hline & & $\mathrm{N}$ & $\%$ \\
\hline Cases & Valid & 23 & 100.0 \\
\hline & Excluded $^{\mathrm{a}}$ & 0 & .0 \\
\hline & Total & 23 & 100.0 \\
\hline
\end{tabular}

a. Listwise deletion based on all variables in the procedure. 
Tabel7.Reliability Statistics

\begin{tabular}{rr}
\hline Cronbach's Alpha & $\mathrm{N}$ of Items \\
\hline .683 & 19 \\
\hline
\end{tabular}

Berdasarkan pengukuran SPSS terhadap analisis reliabilitas kepraktisan LKPD memperoleh hasil sebesar 0,683. Maka dapat dikatakan bahwa isi penilaian kepraktisan LKPD sudah reliabel atau layak digunakan dalam pembelajaran.

Uji keefektifan diujicobakan pada 23 peserta didik kelas $X$ yang sedang mendapatkan pembelajaran usaha dan energi, hasil uji keefektifan LKPD dari keempat bagian yaitu: kemanfaatan, kemudahan pemakaian, kemudahan mempelajari dan kepuasan. Ratarata skor keefektifan LKPD dapat dilihat pada Gambar 3.

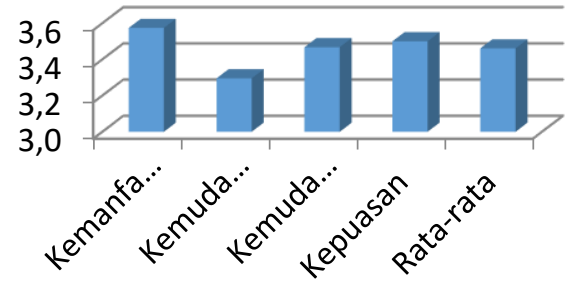

\section{Gambar3.Diagram hasil uji kepraktisan LKPD}

Berdasarkan Gambar 3 dihasilkan skor rata-rata 3,5. Skor ini masuk dalam kategori "Efektif", maka dapat dilihat bahwa LKPD yang dikembangkan dalam proses pendidikan guna mengefektifkan aktivitas dalam kegiatan belajar peserta didik.

Dari hasil rata-rata angket motivasi sebelum dan sesudah diberikan LKPD, akan dianalisis untuk memperoleh hasil peningkatan motivasi belajar peserta didik pada materi usaha dan energi. Analisis kenaikan motivasi belajar peserta didik mengenakan rumus standar Gain. Hasil rata-rata motivasi belajar dapat dilihat pada Gambar 4.

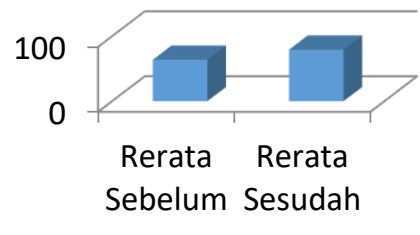

Gambar3.DiagramHasil rata-rata motivasi belajar

Berdasarkan data yang terdapat pada Gambar 1 diperoleh informasi bahwa terjadi peningkatan skor motivasi belajar peserta didik dari sebelum diajar mrnggunakan LKPD berbasis HOTS (pre motivasi) dan setelah diajar menggunakan LKPD berbasis HOTS (post motivasi). Hasil standar gain disajikan pada Tabel 8.

Tabel8. Hasil Standar Gain Motivasi Belajar

\begin{tabular}{clrc}
\hline & Jenis tes & $\begin{array}{c}\text { Pre } \\
\text { motiva } \\
\text { si }\end{array}$ & $\begin{array}{l}\text { Post } \\
\text { motivasi }\end{array}$ \\
\hline & Rata-rata & 63 & 79,3 \\
\cline { 2 - 4 } & &, 9 & \\
\cline { 2 - 4 } $\begin{array}{c}\text { Penilaia } \\
\mathbf{n}\end{array}$ & Skor maks & 96 & \\
\cline { 2 - 4 } & $\begin{array}{l}\text { Standar } \mathrm{N}- \\
\text { Gain }\end{array}$ & 0,48 & \\
\cline { 2 - 4 } & $\begin{array}{l}\text { Klarifikasi } \\
\text { peningkata } \\
\text { n }\end{array}$ & Sedang & \\
\hline
\end{tabular}

Pengembangan lembar kerja peserta didik terintegrasi HOTS yang dianalisis dengan menggunakan rumus $\mathrm{N}$-Gain menunjukkan peningkatan yang signifikan antara nilai angket awal dan angket akhir, rata-rata N-Gain untuk skor motivasi belajar sebesar 96 dengan hasil angket awal sebesar 63,9 dan angket awal sebesar 79,3 sehingga memperoleh rata-rata nilai $\mathrm{N}$-Gain 0,48 pada kategori sedang.

\section{SIMPULAN}

Telah dihasilkan Lembar Kerja Peserta Didik terintegrasi HOTS yang layak dipakai guna menaikkan motivasi belajar peserta didik. Kelayakan LKPD serta fitur pendidikan pendukung ditinjau dari analisis validasi, analisis kepraktisan, serta analisis keefektifan.

LKPD terintegrasi HOTS memperoleh hasil validasi dari keempat bagian ialah: kelengkapan, penyajian, isi dan bahasa, secara universal dihasilkan skor rata-rata 4 serta masuk dalam kategori "Valid". Hasil kepraktisan dari lembar kepraktisan peserta didik memperoleh rata-rata skor $93 \%$ dengan kategori "Sangat Baik" ataupun sangat praktis serta hasil kepraktikan dari lembar kepratikan guru memeroleh skor $85 \%$ dengan kriteria" Baik". Hasil analisis keefektifan LKPD diperoleh skor rata- rata 3,5. Skor ini masuk dalam kategori "Efektif". Besar peningkatan motivasi belajar peserta didik yang memakai LKPD terintegrasi HOTS pada materi usaha dan energi diperoleh dari nilai standar N-Gain ialah sebesar 0,48 dengan kategori sedang.

\section{DAFTAR RUJUKAN}

Adha, I., \& Refianti, R. (2019). Pengembangan Lembar Kerja Siswa (LKS) Menggunakan Pendekatan Matematika Realistik Indonesia Berbasis Konteks Sumatera Selatan. Jurnal Pendidikan Matematika: Judika Education, 2(1), 1-10. 
Arikunto, S. (2017). Pengembangan instrument penelitian dan penilaian program. Yogyakarta: Pustaka Pelajar.

Dhema, M., \& Jufriansah, A. (2021). Aktivitas dan Pemecahan Masalah Matematika Menggunakan Model Problem Based Learning Di SMK. JPMI (Jurnal Pembelajaran Matematika Inovatif), 4(1), 39-44.

Emda, A. (2018). Kedudukan motivasi belajar siswa dalam pembelajaran. Lantanida Journal, 5(2), 172-182.

Faiza, A. S., \& Susilowibowo, J. (2020). Pengembangan Lembar Kegiatan Peserta Didik (LKPD) berbasis HOTS Administrasi Pajak Kelas XII Akuntansi. Jurnal Pendidikan Akuntansi Indonesia, 18(2), 15-27.

Irmawati, M., Rukli, R., \& Baharullah, B. (2019). Pengembangan Perangkat Pembelajaran Matematika Menggunakan Metode Discovery Learning Berbasis GRANDER di Sekolah Dasar. Edumaspul: Jurnal Pendidikan, 3(2), 127-139.

Mustafa, P. S., \& Dwiyogo, W. D. (2020). Kurikulum Pendidikan Jasmani, Olahraga, dan Kesehatan di Indonesia Abad 21. Jurnal Riset Teknologi dan Inovasi Pendidikan (JARTIKA), 3(2), $422-438$

Nazliati, N. (2019). Penggunaan Software Anates Dalam Pembelajaran Evaluasi Pendidikan Pada Mahasiswa Non Matematika Ftik lain Langsa. Al Khawarizmi: Jurnal Pendidikan dan Pembelajaran Matematika, 2(2), 139151

Putri, S. D., \& Djamas, D. (2017). Pengembangan Perangkat Pembelajaran Fisika Berbasis Keterampilan Berpikir Kritis dalam Problem-Based Learning. Jurnal IImiah Pendidikan Fisika Al-Biruni, 6(1), 125.

Saputro, B. (2017). Manajemen Penelitian Pengembangan (Research \& Development) bagi Penyusun Tesisdan Disertasi.

Setiabudi, A., Susanta, A., \&Maulidiya, D. (2019). Efektifitas Lkpd Dengan Pendekatan Saintifik Untuk Meningkatkan Pemahaman Konsep Matematika Siswa Kelas VIII Smp Negeri 3 Kota Bengkulu. Jurnal Penelitian Pembelajaran Matematika Sekolah (JP2MS), 3(2), 228-241.

Sofyan, H., \& Komariah, K. (2016). Pembelajaran problem based learning dalam implementasi kurikulum $2013 \mathrm{Di}$
SMK. Jurnal PendidikanVokasi, 6(3), 260-271.

Tanjung, H. S., \&Nababan, S. A. (2018). Pengembangan perangkat pembelajaran matematika berorientasi model pembelajaran berbasis masalah (pbm) untuk meningkatkan kemampuan berpikir kritis siswa SMA Se-Kuala Nagan Raya Aceh. Genta Mulia: Jurnal Ilmiah Pendidikan, 9(2)

Valencia, U. D., Maizora, S., \&Susanta, A. (2019). Efektifitas Lembar Kerja Peserta Didik (Lkpd) Berbasis Guided Discovery Learning Pada Pokok Bahasan Bangun Ruang Sisi Datar Kelas VIII Smp Negeri 1 Bengkulu Tengah. Jurnal Penelitian Pembelajaran Matematika Sekolah (JP2MS), 3(1), 51-57.

Wahyuningsih, Jufriansah, A., Anomeisa, AB.,Rahmanisa, K. (2021). Strategy on The Effectiveness of Learning Outcomes of Manufacturing Calculus Using Edlink in The Covid-19 Pandemic. Eduma : Mathematics Education Learning And Teaching, 10(1), $39-48$. 